\title{
Contributions of Nurses in Health Education of Patients with Heart Failure REVIEW
}

Maurício Caxias de Souza', Sérgio Ribeiro dos Santos², Ericka Silva Holmes ${ }^{3}$, Wilma Dias de Fontes Pereira4, Aurilene Josefa Cartaxo Gomes de Arruda 4 , Leila de Cássia Tavares da Fonsêca ${ }^{4}$, Felicidade Ferreira Amorim Casanova ${ }^{5}$, Thássia Christina Azevedo da Silva ${ }^{6}$, Thais Dandara Azevedo da Silva ${ }^{6}$, Gerson da Silva Ribeiro7, Nereide de Andrade Virgínio ${ }^{8}$, Claudia Germana Virgínio de Souto ${ }^{8}$, Giselma Leite da Silva ${ }^{9}$, Leandro Bulhões de Lemos Moraes ${ }^{9}$, Marília Roberta Freitas de Vasconcélos ${ }^{9}$, Gyl Dayara Alves de Carvalho7, Laura Cristhiane Mendonça Rezende Chaves ${ }^{7}$, Kirlene Scheyla Viana Chianca ${ }^{7}$, Luciara Cristina Ferreira dos Santos ${ }^{7}$, Saneyde de Carvalho Almeida ${ }^{10}$, Rozileide Martins Simões Candeia ${ }^{11}$

\section{Abstract}

Objective: to identify how health education actions performed by the nursing professional contribute to the improvement of the quality of life of patients with heart failure.

Method: Integrative review built from the following question: What contributions of the nurse in the health education of patients with heart failure? Made in the PUBMED, LILACS and SciELO Virtual Library databases. The studies were analyzed and presented in a descriptive and table format.

Results: 8 studies were the sample. It was possible to identify that the actions of health education developed by nurses to patients with heart failure provide integration of the patients with the family, behavior change and acquisition of healthy habits.
1 Nurse. Member of the Group of Studies and Research in Administration and Informatics in Health, Federal University of Paraiba (GEPAIE/UFPB), *

2 Nurse. Doctor of Sociology. Doctor of Health Sciences. Full Professor of the Clinical Nursing Department of the UFPB. Leader of GEPAIE. Effective Professor of Nursing Graduate Programs (PPGENF/UFPB) and Decision and Health Models (PPGMDS/UFPB), *

3 Nurse. Family Health Specialist (UFPB). PhD student in Decision and Health Models by PPGMDS/UFPB, *

4 Nurse. Professor Doctor. Department of Clinical Nursing. Health Sciences Center (CCS) UFPB, *

5 Nurse. Master in Human Health and Environment by the Pernambuco Federal University (UFPE). Recife, Pernambuco, Brazil.

6 Nurse. Graduated by the Maurício de Nassau College. Brazil.

7 Nurse. Master of Nursing. Postgraduate Program in Nursing of the UFPB. *

8 Nurse. Nova Esperança Nursing College. *

9 Nurse. Residency of Cardiology Nursing at the University of Pernambuco. Recife/PE, Brazil.

10 Nurse. Nurse of the Family Health Program of the Municipality of João Pessoa/Paraiba. *

11 Nurse. Graduated from the Integrated Colleges of Ducks. Patos/PB, Brazil.

Contact information:

Ericka Silva Holmes.

”" ericka_holmes@hotmail.com 
Conclusions: The nurse is a protagonist in the dissemination of knowledge through consultations with people with HF, actions that stimulate self-care, promoting changes that impact on the quality of life of these patients.

\section{Keywords}

Cardiac Insufficiency; Health

Education; Nursing.

\section{Introdution}

Heart Failure (HF) is a chronic and progressive syndrome, evidenced through signs and symptoms of pulmonary and systemic congestion, characterized as the last stage of cardiovascular diseases. [1] It is a disease responsible for high mortality rates, developing both chronic and decompensated, leading to disabling symptoms, frequent hospitalizations, reduced quality of life and a complex therapeutic regimen. $[2,3]$

In general, those affected by this pathology undergo transformations in their lifestyle due to the growing inability to perform their daily activities. These are due to signs and symptoms of the disease manifested by pain, precordial discomfort, dyspnoea, orthopnea, tachycardia, syncope, fatigue and edema. [4]

This syndrome affects about $2 \%$ of the world population and its incidence has increased in the last three decades, especially in the elderly population, where the average age is over 65 years. Despite advances in the treatment of $\mathrm{HF}$, there are high mortality rates and a decrease in the functional capacity of its patients. This increase may be related to the increase in the life expectancy of the elderly person, since HF affects mainly the individuals within this age group. $[5,6]$

In Brazil, there are about two million patients with HF, with 240,000 cases diagnosed per year. Projections indicate that, in 2025, Brazil will have the sixth largest population of the elderly, approximately 30 million people (15\% of the total population). This should result in the multiplication of cases and public spending on this syndrome. [7]
Considered as one of the major public health problems, the IC generates high costs for the health system, collaborating with the increase of readmission rates. [1] With regard to these rates, the expenditure becomes even more worrying when data indicate that the number of patients readmitted with this pathology reaches almost $50 \%$ soon after the first hospitalization due to decompensation, mainly in the period from 30 to 90 days after discharge. This return is considered one of the main risk factors for death in this disease, associated with inadequate therapy, lack of adherence to treatment or worsening of cardiac function. [1, 5]

The treatment of HF includes non-pharmacological measures, pharmacological and in some cases, depending on the stage of the syndrome, surgical measures. However, it is necessary that the nursing orientations are based on self-care teaching, because in this way the individual will become independent and will have autonomy over their treatment. $[8,9]$

Health education is conceptualized as the dialogue between professionals and patients that allows building knowledge and increasing the autonomy of people in their care. It also allows the debate among population, managers and workers, in order to enhance popular control, becoming a mechanism to encourage social management of health. [10]

Among the actions in education and health stand out the participatory activities, whose great differential is the process of interaction between technical knowledge and popular knowledge. Being of fundamental importance that the professional recognizes that the population has a knowledge that 
must be valued during the construction of the educational work, thus favoring the awakening of the autonomy of the patient. [11]

In this context, it is necessary for health professionals to recognize HF patients as active subjects in their own health and capable of changing their history, because when the individual understands their reality, he can raise solutions to transform it. [12] Nurses play an important role in this scenario insofar as they develop health education strategies aimed at patients and their families, aiming to provide a better quality of life for patients with HF. [8]

The high morbidity and mortality rates of patients with HF expose the need for intervention measures through health education by the nursing professional in order to control the signs and symptoms of the disease and a higher quality of life for patients with HF pathology. [8, 11]

Thus, the present study has the objective of to identify how health education actions performed by the nursing professional contribute to the improvement of the quality of life of patients with heart failure.

\section{Method}

This is an integrative review of the current literature, which enables the analysis of relevant research that contributes to the improvement of clinical practice, as well as providing the synthesis of knowledge about a given subject, including the knowledge gaps that need to be fulfilled through new searches. It shows a valuable method for nursing, considering the lack of time of the professionals to carry out the reading and analysis of all the literature of the currently available scientific knowledge. [13]

The following steps were taken to construct an integrative review: establishment of the review objective, selection of articles through inclusion and exclusion criteria, organization of information to be extracted from articles, analysis and presentation of results. [14]
The purpose of the present study was to answer the following guiding question: What are the contributions of the nurse in the health education of patients with HF?

The selection of articles was carried out from August 2015 to August 2016 in the databases: National Library of Medicine (PUBMED), Latin American Literature in Health Sciences and the Caribbean (LILACS), and Scientific Virtual Library Eletronic Library Online (SciELO), using the Health Sciences Descriptors (DeCS): "Health Education", "Heart Failure" and "Nursing", combined by the Boolean operator AND.

The selection criteria of the articles defined for the construction of this integrative review were: articles published in Portuguese, English and Spanish, available in full in the referred databases, between 2010 and 2016, using as descriptors: Health Education AND Insufficiency Cardiac AND Nursing. The exclusion of articles was carried out in those who did not respond to the objective of the review and those who did not present in a clear and objective way the criteria of the research design.

Combining the descriptors, 248 scientific productions were obtained. After applying the inclusion and exclusion criteria, there were 41 articles, 10 in PUBMED, 8 in LILACS and 22 in SciELO. After reading the articles in full, only 8 scientific productions met the objectives of this review.

\section{Results and Discusion}

In the present study, eight articles were analyzed that met the established inclusion criteria, as shown in Table 1.

Through the results, it was possible to perceive that studies have been developed with the purpose of investigating the contributions of the nurses in the health education of patients with HF. Through the titles of the scientific productions, it is observed that these educative actions are directed mainly towards adherence to the treatment and change in the way of life. 
Table 1. Distribution of articles collected, according to the title, year of publication and name of the periodical/database.

\begin{tabular}{|c|c|c|c|c|}
\hline Title & Year & Journal & Data base & Objectives \\
\hline $\begin{array}{l}\text { Health education of patients with heart } \\
\text { failure }\end{array}$ & 2014 & $\begin{array}{l}\text { Nursing } \\
\text { Journal UERJ }\end{array}$ & PUBMED & $\begin{array}{l}\text { Synthesis on health education, through } \\
\text { nursing consultations with patients with HF }\end{array}$ \\
\hline $\begin{array}{l}\text { Factors associated with beliefs about } \\
\text { adherence to non-drug treatment of } \\
\text { patients with HF }\end{array}$ & 2013 & $\begin{array}{l}\text { USP Nursing } \\
\text { School Journal }\end{array}$ & PUBMED & $\begin{array}{l}\text { To evaluate the beliefs regarding benefits and } \\
\text { barriers to adherence to daily self-monitoring } \\
\text { of weight / edema in patients with HF. }\end{array}$ \\
\hline $\begin{array}{l}\text { Education and telephone monitoring of } \\
\text { patients with heart failure: Randomized } \\
\text { Clinical Trial }\end{array}$ & 2011 & $\begin{array}{l}\text { Brazilian } \\
\text { Society of } \\
\text { Cardiology }\end{array}$ & PUBMED & $\begin{array}{l}\text { To compare two groups of nursing } \\
\text { educational interventions among hospitalized } \\
\text { patients with HF }\end{array}$ \\
\hline $\begin{array}{l}\text { Heart failure: expressions of people's } \\
\text { knowledge about the disease }\end{array}$ & 2013 & $\begin{array}{l}\text { USP Nursing } \\
\text { School Journal }\end{array}$ & LILACS & $\begin{array}{l}\text { To analyze the knowledge of people with HF } \\
\text { on the disease and treatment }\end{array}$ \\
\hline $\begin{array}{l}\text { Effectiveness of an educational program } \\
\text { in nursing in the self-care of patients with } \\
\text { heart failure: a controlled clinical trial }\end{array}$ & 2012 & $\begin{array}{l}\text { American } \\
\text { Journal of } \\
\text { Nursing }\end{array}$ & LILACS & $\begin{array}{l}\text { To evaluate the effectiveness of a nursing } \\
\text { education program in improving } \\
\text { the treatment behaviors with HF }\end{array}$ \\
\hline $\begin{array}{l}\text { Discharge plan for patients with } \\
\text { congenital heart failure }\end{array}$ & 2011 & $\begin{array}{l}\text { American } \\
\text { Journal of } \\
\text { Nursing }\end{array}$ & SCIELO & $\begin{array}{l}\text { To identify in the literature how nurses have } \\
\text { planned the discharge of patients with CHF }\end{array}$ \\
\hline $\begin{array}{l}\text { Improvement of self-care behaviors } \\
\text { after. A nursing educational intervention } \\
\text { withPatients with heart failure }\end{array}$ & 2012 & $\begin{array}{l}\text { Research and } \\
\text { Education in } \\
\text { Nursing }\end{array}$ & SCIELO & $\begin{array}{l}\text { To evaluate the improvement in self-care } \\
\text { behaviors after an educational intervention. } \\
\text { Nursing in patients with heart failure }\end{array}$ \\
\hline $\begin{array}{l}\text { Heart failure: strategies used by the } \\
\text { elderly in the search for quality of life. }\end{array}$ & 2011 & $\begin{array}{l}\text { Brazilian } \\
\text { Journal of } \\
\text { Nursing }\end{array}$ & SCIELO & $\begin{array}{l}\text { To describe the strategies used by the } \\
\text { elderly in the face of HF and to know the } \\
\text { perceptions about Nursing Care. }\end{array}$ \\
\hline
\end{tabular}

Source: Survey data, 2016.

Regarding the periodicals of publication, we highlight the Revista Escola de Enfermagem of USP and the Revista Latino Americana de Enfermagem; As for the databases, the ones that presented the greatest productions on the subject were: PUBMED and LILACS. The year 2011 presented a greater number of publications.

It should be pointed out that, among the 8 studies included in this integrative review, 7 of the authors are nurses and one was performed by nurses and physicians. Of the 8 articles, 6 were conducted in Brazil, while the other (2) are of international character, carried out in Colombia.

Regarding the contributions of nurses to health education of patients with $\mathrm{HF}$, the main aspects highlighted by the studies can be seen in Table 2 .

It was possible to observe in the analysis of the articles that the educational actions of nursing profes-
Table 2. Distribution of the articles surveyed, according to the contributions coming from the use of PEP.

\section{Contributions of nurses in health education of patients with heart failure}

Increased adherence to treatment

Weight control and edema

Understanding the pathophysiology of the disease

Changes in eating habits

Improvement of self-care behaviors

Source: Survey data, 2016.

sionals vis-a-vis patients with HF are extremely important in the adequate coping of the disease by these individuals. Among the most outstanding actions by the studies, are the nursing orientations regarding lifestyle changes and self-care behaviors, emphasized by 4 studies. 
Educational interventions regarding the adherence of medication / non-drug therapy to patients with $\mathrm{HF}$ in geriatrics and cardiology outpatient clinics of a university hospital in the interior of the State of São Paulo. It was evidenced that patients with HF perform little weight control and edema, reaching only once a month to verify these measures. The main barrier perceived in the study for adherence to these non-drug measures was pointed out as the forgetfulness and the availability of material, since most of the patients did not have a balance in their homes. [15]

This research concluded that health education programs that employ strategies to identify barriers and benefits for self-care contribute to the understanding that daily weight check and edema can alert the patient to the signs of HF decompensation and avoid The hospitalization, bringing a relevant contribution to the quality of life of these patients. [15]

In relation to health education, in the extra-hospital context, another article shows that a clinical trial was conducted in a university hospital in the city of Porto Alegre, in patients with HF, which were divided into two groups, where G1 received educational intervention of nursing during hospitalization, followed by telephone monitoring after hospital discharge, and $G 2$ received only hospital intervention. In this case, it was verified that the in-hospital nursing educational intervention benefited all patients with HF in relation to the knowledge of the disease and self-care, independent of the telephone contact after discharge. [16] This demonstrates the relevance of the role of nurse educator and the repercussions of this for the quality of life of patients. What should be encouraged not only in primary care but also at the hospital level. [7]

Telephone monitoring can be considered as an additional method of patient investigation, when used to reinforce care plans and the educational process, it is usually used after hospital discharge and in home visitation interventions. Despite the results obtained in this study in Porto Alegre, other experimental studies have shown that HF patients who received this type of education had lower hospital readmission rates when compared to the control group. [17]

Regarding the well-being of these patients, the studies show that the impacts of the disease on the quality of life of people with HF are enormous, besides the physical affections also occur emotional repercussions and even in the financial life of these patients. Welfare is altered, generating incapacities, restrictions on routine habits, limitation of autonomy and independence, especially in the elderly. $[16,17,19]$

A study carried out with elderly patients with HF demonstrated the perception they have regarding the nursing professionals who carry out activities in health education. These patients have reported perceptions related to the affective level, such as attention and affection, empathy in the nursing field is something essential, taking into account that individuals are dealt with in moments of fragility not only biological, but also psychic. It was also verified that the social, educational, economic and cultural context are variables that directly influence the strategies of coping with the disease by those with HF. [12]

In all of the studies analyzed, it was observed that nursing education interventions aim not only to improve knowledge about HF but also, the behaviors that influence the illness. [15-21]

Patients are given nursing care related to medication, food, rest, physical activity, as well as special care referring to the particular conditions of each patient. [20, 21]

\section{Conclusion}

Knowledge about the disease facilitates the adherence of HF patients to the treatment and allows them to develop methods to cope better with the disease, which involves the restriction of liquids and salt in the diet, daily monitoring of weight, physical activities and Regular use of medications. 
The literature has confirmed the benefits related to health education in the various environments where HF can be handled. All the articles analyzed suggest in their results that the nursing educational intervention has a beneficial effect on the self-care behaviors of people with HF and they reveal a significant improvement in the patients' quality of life after being submitted to some type of activity related to health education.

The studies show that in promoting the health of patients with HF, it is not only the administration of medication or the execution of techniques. The educational action and the teaching of new knowledge and behavioral patterns are necessary and the nurse has been acting in a primordial way in the needs and emotions that mediates such knowledge and practices, in order to obtain the best results.

It was possible to verify that the participation of nurses in the practice of educational activities with patients with $\mathrm{HF}$ is extremely important in improving the quality of life of these patients, besides contributing to the development of self-care, introducing changes in lifestyle and facilitating their Treatment adherence. The educational actions developed provide integration of the users with the family, change of behaviors and acquisition of healthy eating habits.

The nurse is the protagonist in the dissemination of education through consultations with patients with HF that goes beyond the simple transmission of knowledge, contextualizing the treatment and promoting changes that affect the quality of life of these patients.

\section{References}

1. Linhares JC, Aliti GB, Castro RA, Rabelo ER. Prescrição e realização do manejo não farmacológico para pacientes com insuficiência cardíaca descompensada [Internet]. Rev. Latino-Am. Enfermagem vol. 18, n. 06, p. 08; 2010 [acesso 2015 ago 05]. Disponível em: http://www.scielo.br/pdf/rlae/v18n6/pt 15.pdf.
2. Castro RA, Rabelo ER, Linhares JC. Adesão ao tratamento de pacientes com insuficiência cardíaca em um hospital universitário [internet]. Rev. Gaúcha Enferm. [online]. vol.31, n.2, p. 225-231; [acesso 2015 jul 12]. Disponível em: http://www.scielo.br/pdf/ rgenf/v31n2/04.pdf

3. Santos I, Sarat CNF. Modalidades de aplicação da teoria do autocuidado de Orem em comunicações científicas de enfermagem brasileira. Rev de Enfermagem UERJ. 2008. 16(3):313-8. Disponível em: http://www.facenf.uerj.br/v16n3/ v16n3a03.pdf

4. Silva ACS, Espírito Santo, FH, Pestana, LC, Daher, DV, Santana, RF. Insuficiência cardíaca: estratégias usadas por idosos na busca por qualidade de vida[Internet]. Rev. Brasileira de Enfermagem. [Online]. 2011, vol 64, n.05. [acesso 2016 set 14]. Disponível em: www.scielo.br/scielo.php?script=sci arttext\&pid $=$ S0034-71672011000500009.

5. I Registro Brasileiro de Insuficiência Cardíaca-Aspectos Clínicos, Qualidade Assistencial e Desfechos Hospitalares[Internet]. Arq Bras Cardiol. 2014. [acesso 2016 set 01]. Disponível em: www.scielo.br/pdf/abc/2015nahead/pt 0066-782Xabc-20150031.pdf.

6. Nogueira PR, Rassi S, Correia, KS. Perfil epidemiológico, clínico e terapêutico da insuficiência cardíaca em hospital terciário[Internet]. Arq. Bras. Cardiol [online]. 2010, vol. 95, n.3 [acesso 2016 ago 08] Disponível em: http://www.scielo.br/pdf/ abc/2010nahead/aop09910.pdf

7. Cavalcanti DCA, Pereira VMJ. Diagnósticos de enfermagem de pacientes com insuficiência cardíaca: revisão integrativa [Internet]. Portal de Revistas de Enfermagem [online]. 2014, vol. 96, n 1. [acesso 2016 ago 30]. Disponível em: http://www.revenf.bvs.br/ scielo.php?script=sci_arttext\&pid=\$1676-4285201400010001

8. Gonçalves FG, Albuquerque DC. Educação em saúde de pacientes portadores de insuficiência cardíaca. Rev. Enferm UERJ [Internet]. Mai.-jun. 2014 [acesso em: 8 mar. 2016]; 22(3):4228. Disponível em: http://www.e-publicacoes.uerj.br/index.php/ enfermagemuerj/article/view/13769

9. SantosI, Rocha RPF, Berardinelli LMM. Necessidades de orientação de enfermagem para o autocuidado de clientes em terapia de hemodiálise. Rev Brasilerira de Enfermagem. 2011. Vol. 64, n.2 [acesso em 2016 set 10]. Disponível em: http://www.scielo.br/ scielo.php?script=sci arttext\&pid=S0034-71672011000200018

10. Ministério da Saúde (BR). Secretaria Executiva. Secretaria de Gestão do Trabalho e da Educação na Saúde. Glossário temático: gestão do trabalho e da educação na saúde. BrasíliaDF: Ministério da Saúde; 2009.

11. Freire P. Pedagogia da autonomia: saberes necessários à prática educativa. 33ª ed. São Paulo: Paz e Terra; 2006. 
12. Freire P. Pedagogia da esperança: um reencontro com a pedagogia do oprimido. 14 ed. São Paulo: Paz e Terra; 2007.

13. Polit DF, Beck CT. Using research in evidence-based nursing practice. In: Polit DF, Beck CT, editors. Essentials of nursing research. Methods, appraisal and utilization. Philadelphia (USA): Lippincott Williams \& Wilkins; 2006. p.457-94.

14. Brevidelli MM, De Domenico EB. Trabalho de conclusão de curso: guia prático para docentes e alunos da área da saúde. $2 a$ ed. São Paulo: látria; 2008.

15. Saccomann, ICRS, Cintra, FA, Gallani, MCBJ. Fatores associados às crenças sobre adesão ao tratamento não medicamentoso de pacientes com insuficiência cardíaca. Revista da Escola de Enfermagem da USP 2014; 48(1):18-24 [acesso em 18 ago 2016]. Disponivel em: http://www.redalyc.org/articulo. oa?id=361033335002. Fecha de consulta: 18 de mayo de 2016.

16. Domingues, FB, Clausell, N, Aliti, GB., Dominguez, DR, Rabelo, ER. Educação e monitorização por telefone de pacientes com insuficiência cardíaca: ensaio clínico randomizado. Arq Bras Cardiol. 2011 96(3), 233-9.

17. Gonçalves, FG, Albuquerque DC. Educação em saúde de pacientes portadores de insuficiência cardíaca [Health education of patients with heart failure]. Revista Enfermagem UERJ. 2014 22(3), 422-426. [acesso em 17 fev 2016]. Disponível em: http://www.e-publicacoes.uerj.br/index.php/enfermagemuerj/ article/view/13769

18. Santos, ACS, Espírito Santo, FH, Pestana, LC, Daher, DV Santana, RF. Insuficiência cardíaca: estratégias usadas por idosos na busca por qualidade de vida. Revista Brasileira de Enfermagem, 2012 64(5):857-63. [acesso em: 10 mar 2016]. Disponível em: http://www.scielo.br/scielo.php?script=sci_artte xt\&pid=S0034-71672011000500009
19. Freitas MTS, Puschel VAA. Insuficiência cardíaca: expressões do conhecimento das pessoas sobre a doença. Revista da Escola de Enfermagem da USP, 2013, 47.4: 922-930. [acesso em 02 jan 2016]. Disponível em: http://www.scielo.br/scielo. php?script=sci arttext\&pid=S0080-62342013000400922

20. Andrietta MP, Moreira RSL, Barros ALBL. Plano de alta hospitalar a pacientes com insuficiência cardíaca congestiva. Revista LatinoAmericana de Enfermagem, 2011 19.6: 1445-1452. [acesso em 27 jan 2016]. Disponível em: http://www.scielo.br/scielo.php?pi $\underline{d}=\$ 010411692011000600023 \&$ script=sci arttext\&tlng

21. Arredondo Holguín, Edith, María de los Ángeles Rodríguez Gázquez, and Lina Marcela Higuita Urrego. Improvement of self-care behaviors after a nursing educational intervention with patients with heart failure. Investigación y Educación en Enfermería 30.2 (2012): 188-197.

22. Gazquez MAR, Holguin EA, Cortes RH. Efectividad de un programa educativo en enfermería en el autocuidado de los pacientes com insuficiencia cardíaca: ensayo clínico controlado. Revista Latino-Americana de Enfermagem 2012 20(2). [acesso em 03 jan 2016] Disponible en: http://www.redalyc.org/articulo. oa?id=281422733012.
Publish in International Archives of Medicine

International Archives of Medicine is an open access journal publishing articles encompassing all aspects of medical science and clinical practice. IAM is considered a megajournal with independent sections on all areas of medicine. IAM is a really international journal with authors and board members from all around the world. The journal is widely indexed and classified Q2 in category Medicine. 